17. Dictionary of Graphic Design and Designers (2003). London: Thames \& Hudson [In English].

18. Frascara, J. (2004). Visual Communications. In book: Communication Design: principles, methods, practice. New York: Allworth Press [In English].

19. Graphic Design History: a critical guide (2013). San Francisco: Pearson Education [In English].

20. Kenney, K. (2009). Visual Communication Research Design. New York: Routledge [In English].

21. Meggs, P. (2006). History of Graphic Design. 5 ed. New York [In English].

22. Mueller-Brockmann, J. (2004). History of the Poster. Berlin [In English].

23. Nelson, R. (1994). The Design of Advertising. Brown company Publishers [In English].

Стаття надійшла до редакції 26.10.2017p.

UDC 7.092:786.2 (477)

Pukhlianko Mariia

Ph.D. in art criticism, associate professor at the

Department of Special piano № 2,

Petro Tchaikovsky National

Music Academy of Ukraine

ORCID 0000-0002-0673-3999

pukhliankomaria@gmail.com

\title{
UKRAINIAN COMPETITIONS OF PIANISTS-PERFORMERS IN THE WORLD CULTURAL SPACE
}

The purpose of this article is to recreate a holistic picture of the Ukrainian competition movement as a component of the global competition system and to identify directions for its further improvement. The research methodology is based on the interrelation of such methods as historical-descriptive and inductive. A number of provisions are based on the results of generalization of empirical observations, as well as the author's own performing and pedagogical experience. The scientific novelty of this work consists in identification of the historical patterns of the establishment and conduct of the pianists performing competitions in Ukraine. Conclusions. Interrelation of the political, economic, social and other processes is indisputable. Cultural phenomena, including performing contests, their activation are a kind of reaction and a means of counteracting both state and international shocks and stagnation.

Keywords: competitions; piano; music performance; young pianists.

Пухлянко Марія Євгенівна, кандидат мистецтвознавства, доцент кафедри спеціального фортепіано № 2 Національної музичної академії України імені П. І. Чайковського

Українські конкурси виконавців в світовому культурному просторі

Мета статті - відтворення цілісної картини українського конкурсного руху як складової глобальної конкурсної системи і визначення напрямків його подальшого вдосконалення. Методологія дослідження базується на взаємозв'язку таких методів як історико-описовий та індуктивний. Ряд положень ґрунтується на результатах узагальнення емпіричних спостережень, а також власному виконавському та педагогічному досвіді автора статті. Наукова новизна роботи полягає у виявленні історичних закономірностей заснування та проведення виконавських змагань піаністів в Україні. Висновки. Незаперечним $є$ взаємозв'язок процесів політичних, економічних, соціальних та ін. Культурні явища, в тому числі і виконавські конкурси, їх активізація - це своєрідна реакція, засіб протидії як потрясінням державного, міжнародного масштабу, так і стагнації.

Ключові слова: конкурси; фортепіано; музичне виконавство; молоді піаністи.

Пухлянко Мария Евгеньевна, кандидат искусствоведения, доцент кафредры специального фрортепиано № 2 Национальной музыкальной академии Украины имени П. И. Чайковского

Украинские конкурсы исполнителей в мировом культурном пространстве

Цель статьи - воссоздание целостной картины украинского конкурсного движения как составляющей глобальной конкурсной системы и определение направлений его дальнейшего совершенствования. Методология исследования базируется на взаимосвязи таких методов как историко-описательный та индуктивный. Ряд положений основывается на результатах обобщения эмпирических наблюдений, а также собственном исполнительском и педагогическом опыте автора статьи. Научная новизна работы состоит в выявлении исторических закономерностей учреждения и проведения исполнительских соревнований пианистов в Украине. Выводы. Неоспоримой является взаимосвязь процессов политических, экономических, социальных и пр. Культурные явления, в том числе и исполнительские конкурсы, их активизация - это своеобразная реакция, средство противодействия как потрясениям государственного, международного масштаба, так и стагнации.

Ключевые слова: конкурсы; фортепиано; музыкальное исполнительство; молодые пианисты.

Relevance of the study. The increased interest in the study of historical, performing-theoretical, methodological issues of piano art naturally reflects the general process of intensifying the study of some musical specializations, national performing traditions and phenomena. Analysis of studies and publications revealed references to Ukrainian music competitions, Ukrainian pianists - the winners of the competition performers. They are contained in the works of L. Barenboim ("Musical pedagogy and performance: articles, 
essays"; "Emil Gilels. Creative portrait of the artist" [1]), Yu. Zilberman ("Kiev College of Music. Essay activities"; "Kiev Symphony by Vladimir Horowitz" [3]), E. Sazonova ("Competition named after Piotr Tchaikovsky. 1958-1978 five competitions: history, reflections"), O. Yablonskaya ("Small hands. Theme with variations"), S. Hentova ("Emil Gilels" [6]); M. Yakovlev ("The Big Rome Prize; Musicians are competing"), etc.

Only separate publications are devoted to the systematic study of the history and specifics of piano competitions of performers in Ukraine: dissertation research and articles by K. Davydovsky ("Creative activity of the Kiev Institute of Music named after R. Glier in the formation of the cultural artistic environment of Kyiv" [2], etc.), articles by E. Zinskaya ("Music contests as a form of actualization of the creative potential of the artist"), E. Kizlova ("Young virtuosos"), reference books by O. Snegirev ("Pianists of Ukraine" - Issues 1-4).

The study of the prehistory of the creation, the prerequisites and the establishment procedure, the specifics of the functioning of some of the leading piano competitions helps to achieve the goals of this article - to recreate a holistic picture of the Ukrainian competition movement as a component of the global competition system and to identify directions for its further improvement.

Statement of basic materials. Since 1930, "...there were Ukrainian competitions of violinists and pianists...", writes L. Barenboim [1, 47]. Exactly they were the historical basis for organizing music competitions in our country.

The Mykola Lysenko International Music Competition (Kyiv) was founded in 1962 on the initiative of the Ukrainian music community. Until 1992, the competition had the status of National and was held in different cities of Ukraine: Kyiv, Odesa, Lviv, Kharkiv, Zaporizhia.

After the proclamation of Independence of Ukraine (1991) the competition receives the status of International in 1992. It has been held in an international format since 1997. A long break between contests (four to five years) is prescribed in the Regulations. This principle was borrowed from other famous competitions, in particular, the model for the organizers was the P. I. Tchaikovsky Competition in Moscow. The official founder of the competition is the Ministry of Culture of Ukraine. According to the Resolution of the Cabinet of Ministers of Ukraine, the state ensures its implementation and guarantees a bonus fund commensurate with the largest, most prestigious competitions held in other countries [2].

The Mykola Lysenko International Music Competition primarily has a brightly national "coloring". The main idea of this musical competition is taken from the very essence of $\mathrm{N}$. Lysenko's activity: to support and multiply the Ukrainian art, "bring it to the world stage". In the personality of the "ideological mastermind" of the competition several cultural traditions were organically combined at once. M. Lysenko received his education in Germany, then in Russia, and built his creative work in Ukraine, relying on the national Ukrainian culture. This personal feature of the founder of Ukrainian music Mykola Lysenko defined the main direction of the International Music Competition - to unite and demonstrate different national cultures on Ukrainian soil.

The Mykola Lysenko International Music Competition is held in several specialties: piano, violin, cello, solo singing (female and male). Over the years, it revealed a whole galaxy of already well-known musicians: L. Martsevych, Yu. Kot, M. Chernyavskaya, E. Chupryk (piano), O. Rivniak, D. Tkachenko (violin), I. Kucher, A. Nuja (cello), L. Zabyliasta, V. Gryshko, N. Shopsha (solo singing), etc.

The last Competition (IVth) was held in 2012. "The project was marked by three events - the 50th anniversary of the founding of the competition (1962), the 170th anniversary of the birth of M. Lysenko, and the 100th anniversary of the death of the composer". Some media experts called it "the most significant event of all music events in Ukraine" [4]. The jury members include laureates of past Lysenko competitions: O. Kozarenko (piano); D. Tkachenko (violin); I. Kucher, Y. Pantelyat, Y. Lanyuk (cello). More than 200 performers from 16 countries took part in the competition. This event was marked by active support (financing, organizational and informational support) of the Ministry of Culture. "For the first time, television was connected to the competition - this is a live broadcast of the closing procedure of the competition, and the same television advertising, which is usually not available for events of this kind", notes O. Kononenko, the artistic director of the competition [4].

Work on the restructuring of the competition continues at the moment. First of all, this is connected with the desire to improve the organization of the conduct, "in order to be on the same level with other prestigious international competitions" [4].

International Competition for Young Pianists in Memory of Vladimir Horowitz is a model for competitive functionaries of Ukraine. K. Davydovsky calls this "cultural and artistic" project one of the "resonant initiatives" of the Kyiv Institute of Music named after R. Glier. [2, 1]. Nowadays it is the largest performing forum promoting the achievements of the Ukrainian piano school in the whole world.

The proclamation of Independence of Ukraine preceded the organization of the competition. The transition to a market economy caused an aggravation of the socio-economic situation in the country, this caused an aggravation of the political situation also. At this moment, the initiative group of teachers of the Kiev Musical College (now Kiev Institute of Music) named after R. Glier, headed by Y. Zilberman, was decided to establish a competition in memory of V. Horowitz (1994). Later, they created the Directorate of the competition, established the non-governmental organization International Charitable Foundation of the Competition V. Horowitz, carried out a number of musical projects. The historical fact of the biography confirming that the great pianist of the 20th century V. Horowitz studied at the Kyiv Music School and, possibly, at the 
Kyiv Conservatory (classes of V. Pukhalsky, S. Tarnovsky and F. Blumenfeld) became the ideological impetus for the organization of events in Kyiv. "This find prompted the idea to organize a competition for young pianists in memory of a brilliant graduate" [3, 3].

The first competitive auditions were held in 1995. Since then, 11 contests have been held, and the 12th is scheduled for April 2019. The competition is held in three age groups: junior, intermediate and senior. There is also a group of "Horowitz-Debut" [8].

Famous Ukrainian musicians: performers, conductors, composers - I. Karabyts, R. Kofman, M. Skorik, O. Zlotnyk, V. Kozlov headed the jury of the competition in different years. Foreign members of the jury are represented by the names of authoritative pianists: D. Bashkirov, V. Viardo (Russia), E. Krasovsky (Israel), D. Rose, D. Loventhal, O. Yablonskaya (USA), F. Waterman (Great Britain), S. Perticaroli, H. Stupner (Italy), W. Thomson (Australia), M. Rybicki (France), etc. Young Ukrainian performers have repeatedly become laureates of the Competition. Some of them, including A. Baryshevsky, A. Gavrilyuk, O. Grinyuk, M. Kim, E. Kulikova, D. Onishchenko, O. Polyakov, M. Pukhlianko, P. Sasko, V. Kholodenko, etc., after the victory, they managed to achieve a certain international fame, having won in other major international competitions.

\section{תimepamypa}

1. Баренбойм Л. Эмиль Гилельс. Творческий портрет артиста. М. : Советский композитор, 1990. 263 с.

2. Давидовський К. Ю. Творча діяльність Київського інституту музики ім. Р. М. Глієра у формуванні культурного мистецького середовища Києва (1991-2010рр.) : автореф. дис. ... кандидата мистецтвознавства : спец. 26.00.01 - Теорія та історія культури. К., 2012. 20 с.

3. Зильберман Ю., Смилянская Ю. Киевская симфония Владимира Горовица. К., 2002. 412 с., ил.

4. Константинова Е. Конкурс Лысенко: попытка №4 // Дзеркало тижня. Україна. К., 16 листопада 2012. Режим доступу: http://gazeta.zn.ua/CULTURE/konkurs_lysenko_popytka_4.html

5. Положення про Міжнародний музичний конкурс імені Миколи Лисенка. Режим доступу: http://zakon2.rada.gov.ua/laws/show/z0430-07

6. Хентова С. Эмиль Гилельс. М. : Гос. муз. изд-во, 1959. 183 с.

7. http://www.competition.kiev.ua

8. http://www.horowitzv.org

\section{References}

1. Barenboim L. Emil Gilels. Creative portrait of the artist. M. : Soviet composer, 1990. 263 p. [in Russian].

2. Davydovsky K. Yu. Creative activity of the Kyiv Institute of Music named after. R. Glier in the formation of the cultural artistic environment of Kiev (1991-2010): author's abstract. dis. candidate of art studies: specialist. 26.00.01 Theory and history of culture. K., 2012. 20 p. [in Ukrainian].

3. Zilberman U., Smilyanskaya U. Kiev Symphony of Vladimir Horowitz. K., 2002. 412 p., ill. [in Russian].

4. Konstantinova E. Lysenko Competition: Attempt \# 4 // Dzerkalo Tyznya. Ukraine. K., November 16, 2012. Access mode: http://gazeta.zn.ua/CULTURE/konkurs_lysenko_popytka_4.html. [in Russian].

5. The Regulations on the International Music Competition named after Mykola Lysenko. Access mode: http://zakon2.rada.gov.ua/laws/show/z0430-07 [in Ukrainian].

6. Khentova S. Emil Gilels. M. : State. music publishing house, 1959. 183 p. [in Russian].

7. http://www.competition.kiev.ua

8. http://www.horowitzv.org 